\title{
Pedagogical Application of Corpus on EFL of Children with Autism Spectrum Disorders (ASD): The Function of Visualization on Attention Deficit Problem
}

\author{
Jing Shi ${ }^{1}$ \\ ${ }^{1}$ School of English for International Business, Guangdong University of Foreign Studies, Guangzhou, \\ Guangdong, P.R. China \\ Correspondence: Jing Shi, School of English for International Business, Guangdong University of Foreign \\ Studies, Guangzhou, Guangdong 510420, P.R. China. E-mail: sj@oamail.gdufs.edu.cn
}

Received: June 25, 2018 Accepted: August 9, 2018 Online Published: August 16, 2018

doi:10.5539/jedp.v8n2p120 URL: http://doi.org/10.5539/jedp.v8n2p120

\begin{abstract}
Statistics reveals that Autism Spectrum Disorders (ASD) becomes prevalent in recent years. Among 68 children, 1 is reported as being on the spectrum. Children with ASD often encounter a variety of challenges in their academic life, most of which are supposed to be attributed to the core symptoms of ASD. This study attempts to explore the effects of the pedagogical application of corpus on children with ASD by analyzing the visualization function of corpus tools on children with ASD. This research involves 30 children (aged 8-10) who have been diagnosed as being with ASD on the mild side. They have spontaneous utterances in their L1 and most of which are of pragmatic functions. Compared with the normally developed peers, these 30 children have shown difficulties in learning a foreign language. This article assesses the visualizing function of the pedagogical application of corpus on helping them overcome the difficulties: they can be seated longer during the class; they pay more attention to the instructor and peers; and they respond more frequently to the instructor and peers. Hopefully, this article can provide some constructive suggestions for foreign language teaching and learning for children with ASD.
\end{abstract}

\section{Introduction}

Autism, a complicated and chronic neurodevelopmental condition, which is characterized by developmental deficits in socialization and communication. Children with ASD usually exhibit undesired delay in language acquisition and other language impairment problems. There is a tradition of support for language pedagogy throughout the history in education, especially in China's context. Globalization and China's ever-increasing importance in the international community have had a dramatic impact on desire to achieve the best possible results in foreign language learning. It is an achievable goal for typically-developed children to have a good command of a foreign language, but for children with ASD this might be challenging or even burdensome. It is usually regarded as impossible for children with ASD to learn a foreign language since generally children on the spectrum are with language impairment problems. However, most of the children with ASD tend to be detail-obsessed: they pay more attention to details rather than big picture. At the elementary level of foreign language learning, it is usually detail-oriented and the concrete process of foreign language learning might be comforting for children with ASD who are often anxious about unpredictable situations.

There is a dearth of published research in the area of ASD and foreign language teaching and learning; however, all of the available research reveals that there is no negative impact of foreign language learning on language development of children with ASD. Quite on the contrary, learning a foreign language might impose positive effects on the language development of children with ASD in terms of social interaction and communication. If learning a foreign language could benefit the language development of children with ASD, what would possible be the most effective way of helping them with their foreign language learning? Generally, children with ASD might have problems with receiving information via listening, but they have advantage in visual learning. Visual prompts are necessary to make their learning easier and more effective and efficient. Pedagogical application of corpus tools and their visualizing function are introduced in the English teaching and learning program. 


\section{Theoretical Framework}

\subsection{Visualization Advantage of Children With ASD}

The processing of visual aids like images is much faster than that of a language, according to research on cognitive development. Images, rather than words, are easier to be retained in long-term memory (Levie \& Lentz, 1982). The effective scaffolding function of images are beneficial for learners' comprehension of language (Beck, McKeown, $\&$ Kucan, 2002). The schemata, which refers to the result of our experience and memory, is the foundation of our observation and comprehension of images. For learners who have limited vocabulary and grammatical structure, visual aids provide loads of help. More importantly, visual aids are able to fade away for effective communication. Our aim is to transform learners' reliance on images and deepen their understanding of visual aids. Learners at the elementary level can improve their language ability by labeling images. The complexity of lexis and the length of sentences could be increased with learners' comprehension of images being strengthened. Children on the spectrum are easily attracted by salient features of images, which can compensate for their disadvantage in attention.

The advantage of ASD children's visualization ability are of three features: 1) children with ASD attend to information both in the center and the other parts (Ruthefford, 2007); 2) it is challenging for children with ASD to focus on one focal point; 3 ) children with ASD tend to process information in a bottom-up style and very often they are obsessed with details rather than the big picture. Therefore, the pedagogical application of corpus should satisfy children's requirements and cater to the features of their visual learning ability.

\subsection{Attention Deficit: Vital Reason for Low Achievement in ESL}

Researches from Ferrari and Palladino (2007), and Vargas et al. (2002) have pointed out the correlation between low achievement in English language learning and attention deficit. Because of the neurodevelopmental problem, children with ASD find it challenging to focus on teaching items for a longer time and very often they feel frustrated with their low achievement in language learning, which is deemed to be the vicious cycle for them. The audio input is not welcomed by children with ASD as they find it difficult to comprehend. In that case, instructors can resort to visual input. What type of visual input is suitable for children with ASD? Can the pedagogical application of corpus impose positive effects on children with ASD? Can the visual images generated by corpus-based program aid ASD learners' comprehension? These research questions will be answered via the implementation of corpus linguistics in their lexical teaching and learning and the effectiveness of the implementation will be assessed.

\section{Visualization Function of Pedagogical Application of Corpus}

The corpus-based program used in the pedagogical application in this research is called LancsBox (Brezina, 2015), which is designed to improve English language learners' lexical teaching and learning ability. Its powerful function mainly lies in that it can generate a variety of visual images of words. The implementation of LancsBox in this research is elaborated as follows. First, a corpus of approximately 4000 words has been compiled, which is from Songbirds Phonics Storybooks published by Foreign Language Teaching and Research Press in China; and from the reading comprehension worksheets downloaded from Education.com.. This mini-corpus contained fiction and non-fiction stories which are designed for children from age 4 to 11 . Once the mini-corpus has been accomplished, LancsBox has been put into use. LancsBox is a user-friendly corpus-based system and even the instructors without any experience with any corpus-based research engine will have no problem in using it. Picture 1 is the word cloud generated by the program and the most frequently-appearing words are in the largest size. The salient feature can be easily noticed and spotted by children with ASD who have a strong visual learning ability. In Picture 2, the instructor can have an overview of the whole corpus. 


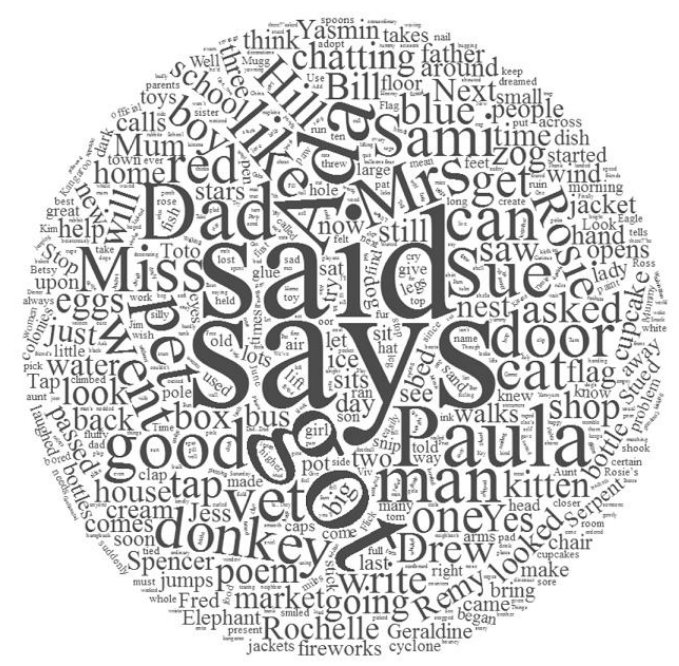

Picture 1. Word cloud for the corpus

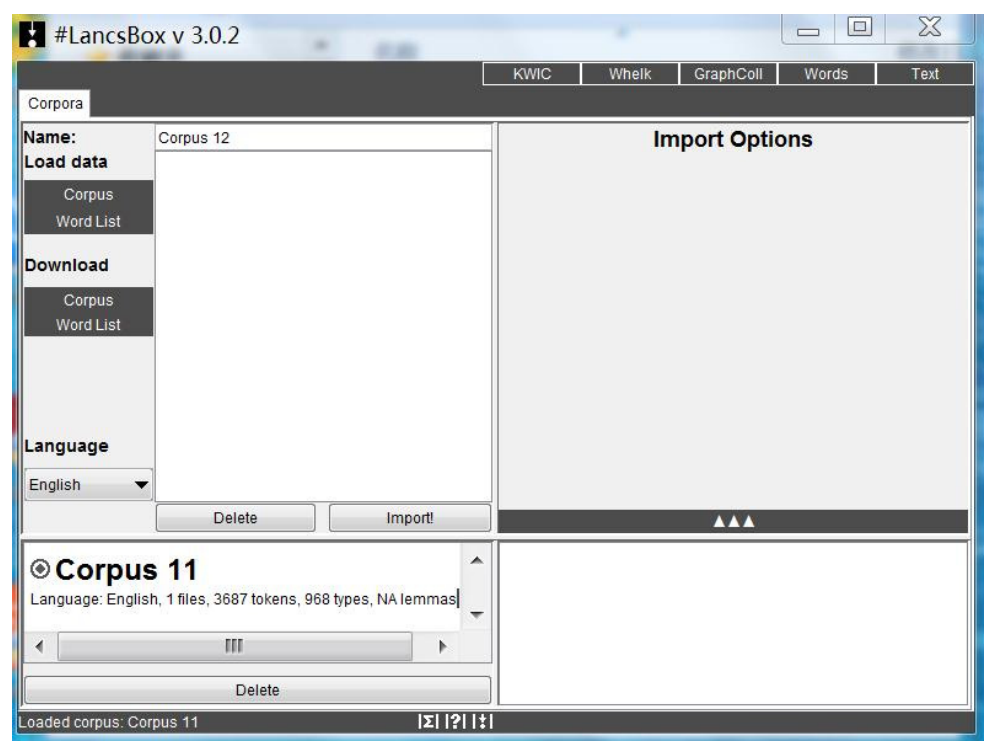

Picture 2. Corpus overview by LancsBox

After that, instructor can obtain more visual information by using the program. Picture 3 is the wordlist for the corpus and the most frequent verbs and adjective are selected to illustrate how the program generate visual images to aid ASD children's lexical teaching and learning. 


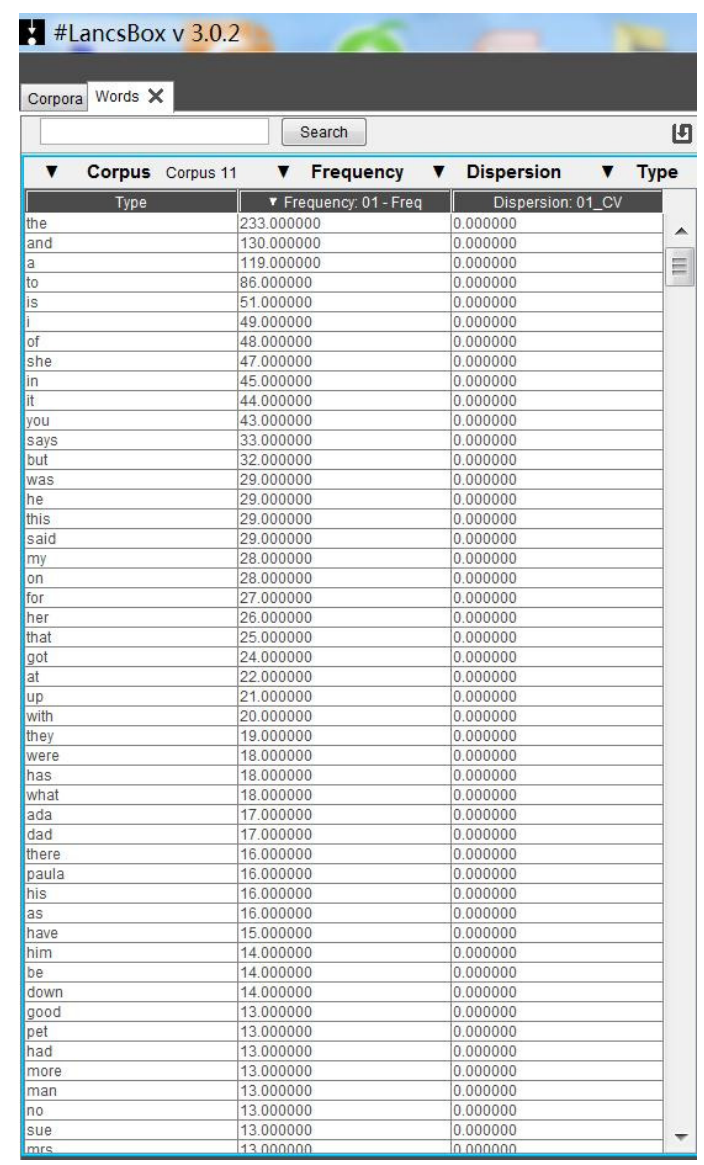

Picture 3. Word list of the corpus

By clicking "Graphcoll" and type in the most frequent verbs "says" and "said" respectively, the user can generate Picture 4, a collocation graph, indicating the relationship between the node and the other words. Even the collocation strength has been visualized: the most frequent collocations are closest to the node word.

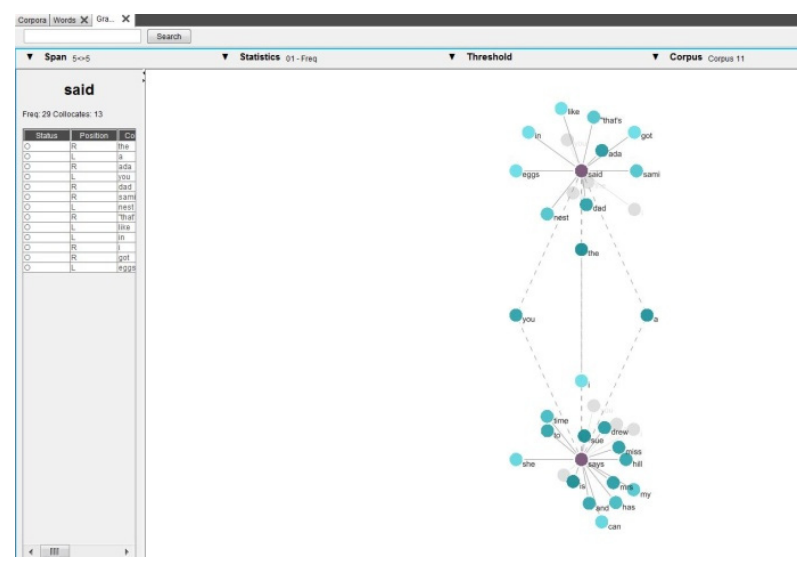

Picture 4. Collocation graph for the most frequent verbs "says" and "said" 


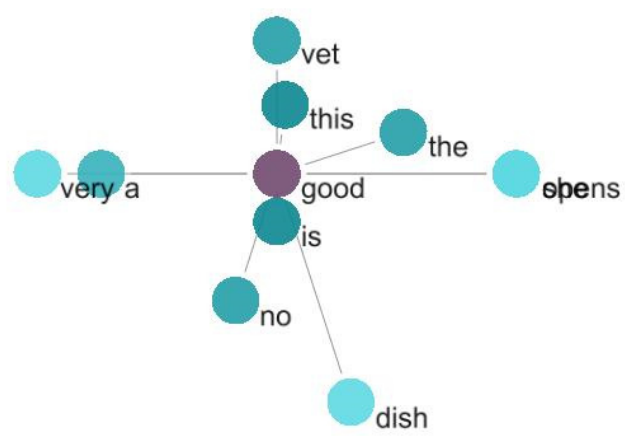

Picture 5. Collocation graph for the most frequent adjective "good"

Picture 5 demonstrates the collocation of the keyword "good" in this corpus. Learners can easily attend to the collocation of the node word and also the relationship between them.

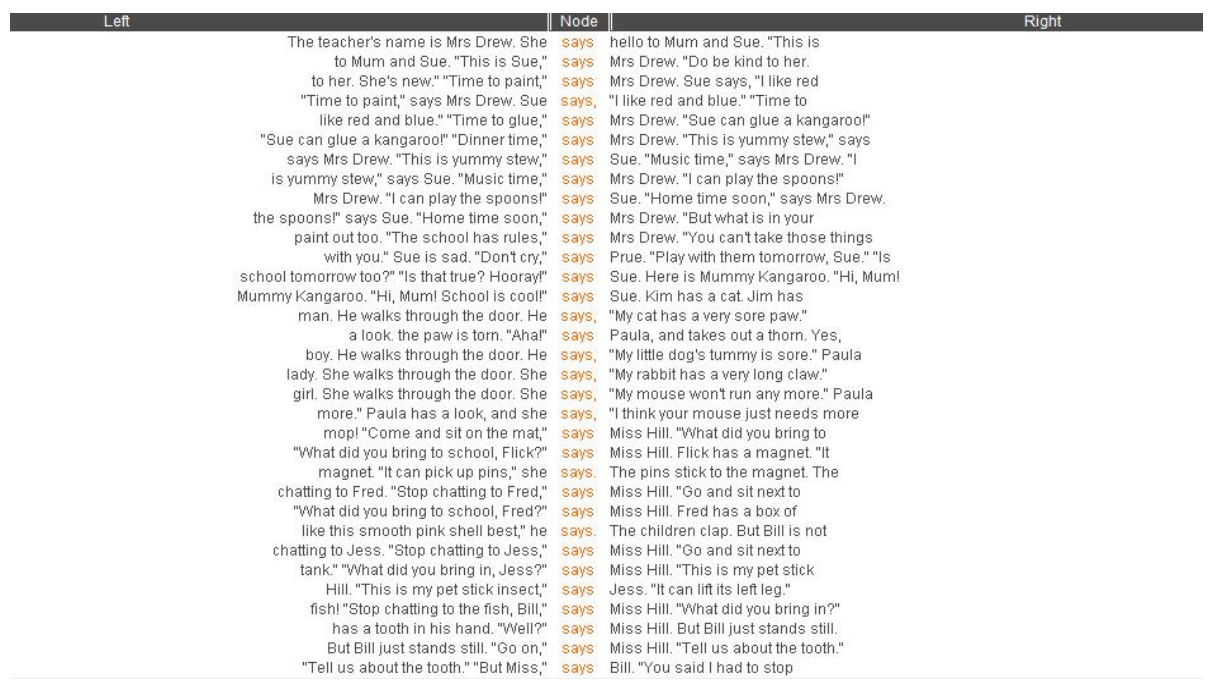

Picture 6. Key-Word-in-Context (KWIC) format of "says"

If the learner is interested in and capable of obtaining more information of the key word, he can click on the "KWIC" button, and the above (Picture 6) lexical information will be displayed and the learner can get to know more authentic language use. The key word is highlighted, which aims to grab learners' attention. The salient feature is of great importance towards children with ASD.

\section{Research Design and Methods}

\subsection{Settings and Participants}

Participants of the research are children aged 8 to 10, studying in an intervention center for children with ASD. They have been diagnosed as being autistic in accordance with the standard listed in DSM-V (2013). They were stratified into males and females consecutively recruited. This classification was to compensate for the male to female ratio of ASD cases in the intervention center as generally more males than females are diagnosed as ASD. The parents of the potential participants of the research were approached by the researcher for consent to enroll in the study. Ethical approval was obtained from the participants' parents and the intervention center.

30 children, aged 8 to 10,15 males and 15 females respectively, participated in the research. They have been assessed in accordance with the Verbal Behavior Milestones Assessment and Placement Program (VB-MAPP) (Sundberg, 2017) which is based on Skinner's theory of verbal behavior and all the participants are in the Stage III which is on the upper side of the scale. They all have appropriate aptitude of native language and their intelligence 
quotient is above 70 via Wechsler Intelligence Scale for Children-IV (Prifitera et al., 2008). All of them are High-Functioning ASD children.

\subsection{Testing Measure and Administration}

Although their cognitive ability is preserved, they still have problems in daily interaction and communication with their normally-developed peers. On one hand, the core of their impairment is lack of social skills. Social skills can be defined as specific behaviors leading to effective social interactions (Elliott \& Gresham, 1987; Gresham, 1986 and Rao et al., 2008). Social skills can basically be divided into three aspects: 1) smiling and making eye contact; 2) asking and responding to questions; 3) giving and acknowledging complaints (Rao et al., 2008). On the other hand, since the comorbidity between ASD and attention deficit exists, and the main reason for ASD children to become low-achievement language learners is attention deficit. Based on these two reasons, testing measures attend to two factors: social communication and attention response. Social communication is gauged in terms of frequencies: 1) glances at the instructor within 15 minutes; 2) times of asking and responding to questions in one lesson of 40 minutes. Attention response is evaluated in terms of time duration (Vargas et al., 2002): 1) viewing time of teaching materials; 2) response time to instructor's teaching. Data are collected five times respectively before and after the three-month implementation of the pedagogical application of corpus linguistics to assess the effectiveness of the pedagogical application of corpus linguistics.

\subsection{Data Collection and Analysis}

Children on the spectrum usually lack eye contact because of their impaired communication skills. After the implementation of the innovative method, the frequencies of eye contacts are increased as illustrated in the following graph (Figure 1). Learners are more engaged in the class than before, since the times that they respond to the instructor's questions and that of proposing questions are also increased (Figure 2). Children with ASD usually have problems in shifts from people to items. Their attention is easily fixed on certain items and hard to be changed onto people. Taking advantage of their visual strength can enable them to be more involved in the class. Their viewing time of the teaching materials (Figure 3 ) and their response time within a lesson of 40 minutes (Figure 4) are also increased. Collected data reveals that the visual learning has been strengthened and they become more interested in English language learning. Their language awareness has been raised as they become more involved in the classroom.

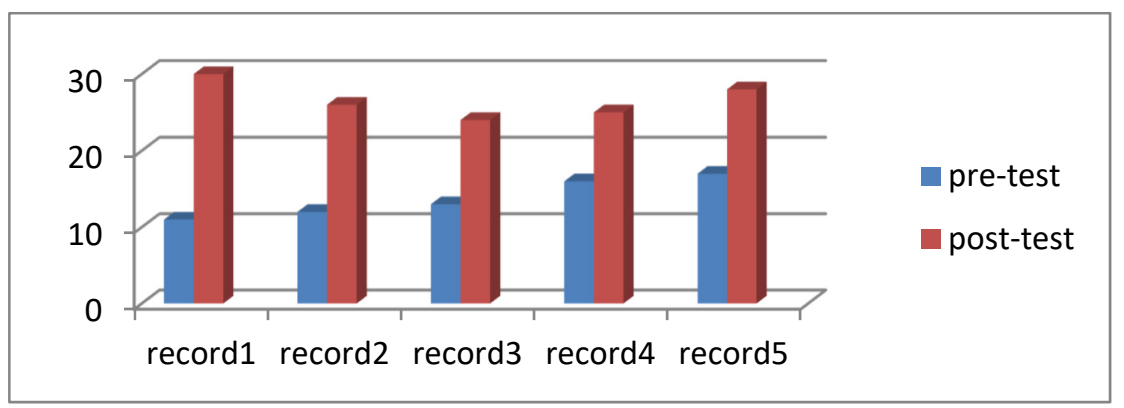

Figure 1. Frequencies of glances at the instructor within 15 minutes

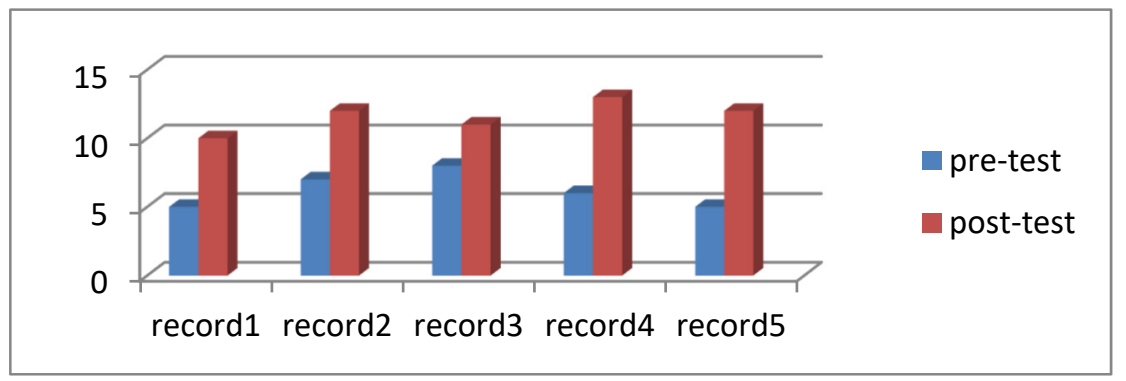

Figure 2. Times of asking and responding to questions in one lesson of 40 minutes 


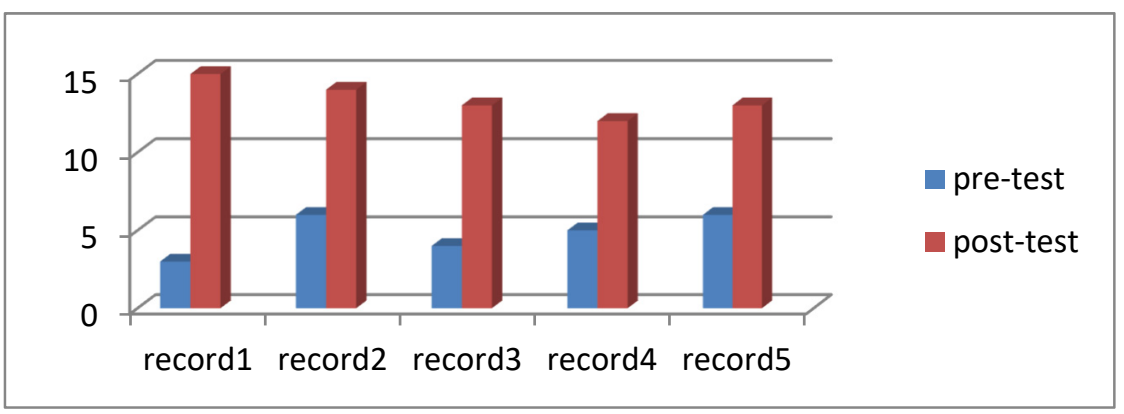

Figure 3. Viewing time of teaching materials (in seconds)

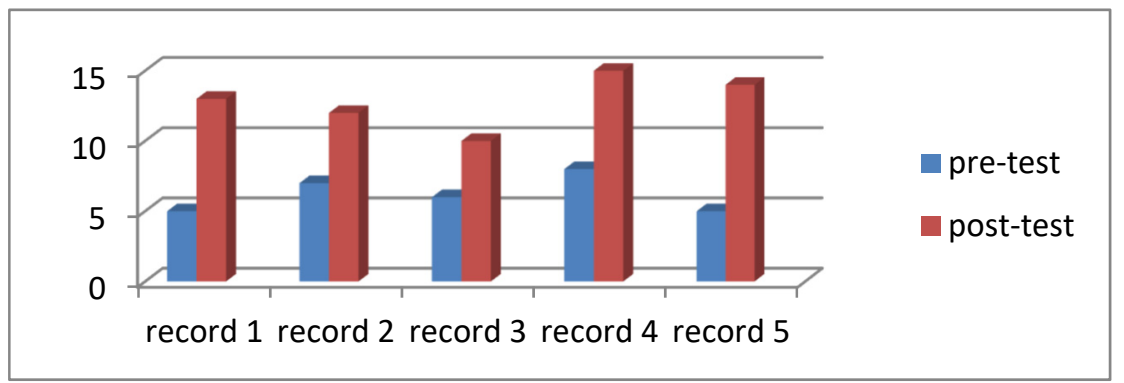

Figure 4. Response time in one lesson of 40 minutes

\section{Conclusion}

The prevalence of ASD is a worldwide phenomenon. The number of High-Functioning ASD children are increasing dramatically. These children's cognitive and language abilities are within the normal range, which means they have the qualification to get enrolled in mainstream schools. Inclusion is not an easy task for both learners and instructors. ASD learners have a different way of language input: their visual learning advantage can enable them absorb more language knowledge than their normally-developed peers. Statistics reveal that the visualization function of the pedagogical application of corpus benefits their English language learning, in terms of higher frequencies in responding and more time in being engaged in class. Having a good command of English can endow them with more opportunities to explore the world and this could enable them to be more intrusive, investigative and engaging. For High-Functioning ASD, it is not impossible for them to master another language. However, this research covers very limited aspects of English language learning for children with ASD and the pedagogical application of the corpus is only partial. In what other ways could the pedagogical application of corpus benefit the ASD learners? Could this method also be useful for low and medium functioning ASD learners? More research work in this field needs to be done, and the research itself will be challenging but rewarding as well.

\section{Acknowledgments}

This article is sponsored by the research project "Pedagogical Application of Corpus on Learners' Language Awareness" (Project Code: GD15WZ06), supported by the Guangdong Planning Office of Philosophy and Social Science.

\section{References}

American Psychiatric Association. (2013). Diagnostic and Statistical Manual of Mental Disorders (5th ed.). DSM-V. Washington, DC: American Psychiatric Association.

Beck, I. L., McKeown, M. G., \& Kucan, L. (2002). Bringing words to life: Robust vocabulary instruction. New York: Guilford.

Brezina, V., McEnery, T., \& Wattam, S. (2015). Collocations in context: A new perspective on collocation networks. International Journal of Corpus Linguistics, 20(2), 139-173. https://doi.org/10.1075/ijcl.20.2.01bre

Chan, G. F. C., Lai, K. Y. C., Luk, E. S. L., Hung, S. F., \& Leung, P. W. L. (2014). Clinical utility of the Chinese 
strengths and weaknesses of ADHD-symptoms and normal-behaviors questionnaire (SWAN) when compared with DISC-IV. Neuropsychiatric Disease and Treatmen, 10, 1533-1542. https://doi.org/10.2147/NDT.S65879

Elliott, S. N., \& Gresham, F. M. (1987). Children's social skills assessment and classification practices. Journal of Conseling and Development, 66, 96-99. https://doi.org/10.1002/j.1556-6676.1987.tb00808.x

Ferrari, M., \& Palladino, P. (2007). Foreign language learning difficulties in Italian children: are they associated with other learning difficulties? Journal of Learning Disabilities, 40(3), 256-269. https://doi.org/10.1177/00222194070400030601

Gresham, F. M. (1986). Conceptual and definitional issues in the assessment of children's social skills: implications for classification and training. Journal of Clinical Child Psychology, 15(1), 3-15. https://doi.org/10.1207/s15374424jccp1501_1

Levie, W. H., \& Lentz, R. (1982). Effects of text illustrations: A review of research. Educational Communications and Technology Journal, 30(4), 195-232.

Paradis, J. (2007). Bilingual children with specific language impairment: theoretical and applied issues. Applied Psycholinguistics, 28(3), 551-564. https://doi.org/10.1017/S0142716407070300

Prifitera, A., Saklofske, D. H., \& Weiss, L. G. (2008). WISC-IV Clinical Assessment and Intervention (2nd ed.). 2 San Diego: Academic Press.

Rao, P.A., Beidel, D. C., \& Michael, J. M. (2008). Social skills interventions for children with Asperger's syndrome or high-functioning autism: a review and recommendations. Journal of Autism and Developmental Disorders, 38, 353-361. https://doi.org/10.1007/s10803-007-0402-4

Ruthefford. M. D., Richards E. D., \& Moldes, V. (2007). Evidence of a divided attention advantage in autism. Cognitive neuropsychology, 24(5), 505-515. https://doi.org/10.1080/02643290701508224

Sundberg, M. L. (2017). Verbal Behavior Milestones Assessment and Placement Program-Chinese version. Beijing: Beijing University Press.

Vargas, A. U., Zentall, S. S., \& Wilbur, J. D. (2002). Response to art attention-training by English and bilingual Spanish-speaking students with and without ADHD. Studies in Art Education, 43(2), 158-174. https://doi.org/10.2307/1321002

\section{Appendix 1: Scripts from Songbirds Phonics Stories (Stage I-V)}

\section{Story 1}

Ada had a nest. "What have you got there?" asked Mum. "One...two... three eggs in a nest," said Ada. "That's not a nest!" said Mum. "That's my old red hat!" "I'm going to sell the eggs at the market," said Ada. Ada got on the bust to go to market. A boy on the bus saw Ada. "What have you got there?" he asked. "One...two...three eggs in a nest," said Ada. "That's not a nest!" said the boy. "That's an old red hat!" A lady on the bus saw Ada. "Let me see. What have you got there?" she asked. "I have got one...two...three eggs in a nest," said Ada. "I'll give you three pennies for the eggs," said the lady. Ada got off the bus at the market. A man at the market saw Ada. "What have you got there?" he asked. "One...two...three pennies!" said Ada. "What can I get with three pennies?" "Give me the three pennies and you can have this," said the man. Ada got back on the bus. A girl on the bus saw Ada. "What have you got there?" she asked. Ada shook her head and smiled. She got off the bus and went home. Mum saw Ada. "What have you got there?" she asked. "It's for you," said Ada. It was a new red hat! "Thank you, Ada!" said Mum.

\section{Story 2}

This is school and this is Sue and this is Mummy Kangaroo. The teacher's name is Mrs Drew. She says hello to Mum and Sue. "This is Sue," says Mrs Drew. "Do be kind to her. She's new. "Time to paint," says Mrs Drew. Sue says, "I like red and blue." "Time to glue," says Mrs Drew. "Sue can glue a kangaroo!" "Dinner time," says Mrs Drew. "This is yummy stew," says Sue. "Music time, "says Mrs Drew. "I can play the spoons!" says Sue. "Home time soon," says Mrs Drew. "But what is in your pocket, Sue?" Sue takes out a tube of glue. She takes some spoons and paint out too. "The school has rules," says Mrs Drew. "You can't take those things home with you. "Sue is sad. "Don't cry, "says Prue. "Play with them tomorrow, Sue." "Is there school tomorrow too?" "Is that true? Hooray!” says Sue. Here is Mummy Kangaroo. "Hi, Mum! School is cool!” says Sue. 


\section{Story 3}

Kim has a cat. Jim has a dog. But Viv has an odd pet. It is a zog! Not a cat, not a dog, but a zog! The zog is fat. It has ten red legs. It can run and hop. It can sit and beg. The zog has lots of eggs! The zog sits on the eggs. It sits and sits. Tap, tap, tap! Tap, tap, tap! Lots of zogs! Now Kim has a cat and a zog. Jim has a dog and a zog. And Viv has ten zogs!

\section{Story 4}

Paula is a vet and a very good vet. She opens the door and she calls, "Next pet!" Here comes a man. He walks through the door. He says, "My cat has a very sore paw." Paula has a look. the paw is torn. "Aha!" says Paula, and takes out a thorn. Yes, Paula is a vet and a very good vet. She opens the door and she calls, "Next pet!" Here comes a boy. He walks through the door. He says, "My little dog's tummy is sore." Paula tells the boy, "Your dog is ill, but she'll soon get better if she takes this pill." Yes, Paula is a vet and a very good vet. She opens the door and she calls, "Next pet!" Here comes a lady. She walks through the door. She says, "My rabbit has a very long claw." Paula tells the lady, "The nail needs a clip." Paula gets her scissors-- snip, snip, snip! Yes, Paula is a vet and a very good vet. She opens the door and she calls, "Next pet!" Here comes a girl. She walks through the door She says, "My mouse won't run any more." Paula has a look, and she says, "I think your mouse just needs more water to drink." All the morning, Paula the vet sees a pet, after pet, after pet, after pet. More and more dogs, more and more cats, more and more rabbits and mice and rats. Paula sees ordinary pets all morning. Paula feels bored. Paula starts yawning. "It's always the same, "thinks Paula the vet. "I wish I could see an extraordinary pet!" But Paula the vet is very good vet. So she opens the door and she calls, "Next pet!" Here comes someone. He walks through the door. It's a very small boy...with a dinosaur!

\section{Story 5}

Yasmin and Dad went to the bank. Next, they went shopping. Yasmin held the shopping list. Yasmin and Dad went to a big shop. They got in the lift. A man got in with them. Yasmin and Dad got back in the lift. The man got in with them. Yasmin and Dad went back home.

\section{Story 6}

I'm going to write a poem. I find a pot of ink. I find a pen. I find a pad. I scratch my head and think. I try to write a poem about my mum and dad. But then the cat jumps on the desk and sits upon my pad. I try to write a poem about the sea and sand. But then the cat jumps up and knocks the pen out of my hand. I try to write a poem about a bright red rose. But then the cat jumps up again and licks me on the nose. I know! I'll write a poem about a humpback whale. This time the cat jumps up and knocks the ink off with his tail. That silly cat keeps bugging me! I pick him up and say, "If you won't let me write my poem, then I won't let you stay." The cat sits on the window sill. He looks so cold and sad. I try to write my poem but I can't help feeling bad. I suck my pen. I scratch my head. I think of this and that. Then suddenly I've got it! "I'll write about..." "My cat!"

Story 7

I am in the wood! La la la...They look good! Yum-yum! This dish is no good! This dish is no good! This is the right dish for me! This chair is no good! This chair is no good! This is the right chair for me! I will go into the bedroom. This bed is no good! This bed is no good! This is the right bed for me! Look at my dish! Look at my chair! Look at my bed!

\section{Story 8}

Dad bought Sami a new jacket. "Thanks, Dad!" said Sami. "Do you like it?” asked Dad. "Yes," said Sami. "I like the jacket-- but I don't like green." "No problem," said Dad. "Let's take it back to the shop and get you a blue jacket." Dad and Sami went to town. They went to the shop but there were no blue jackets. "Let's look at the red jackets," said Dad. Then Dad met a friend. Sami was bored. He looked at the red jackets. then he looked at the football boots. Then he looked for Dad...Dad wasn't there. There were lots and lots of people but Dad was not there! Sami went up to a shop assistant. "Please, can you help me?" he said. "I've lost my dad." "No problem," said the shop assistant. Sami and the shop assistant looked for Dad. "That's him!" said Sami. "The one in the green jacket!" "Let's go home now," said Sami. "There are too many people in town." "Yes," said Dad. "But what about your jacket?" "No problem, "said Sami. "I'm going to keep the green one." "But you don't like green," said Dad. "I do now," said Sami.

\section{Story 9}

Tom got a pot. Pam got a pot. Sam got a pot. Pat, pat, pat! Tap, tap, tap! Tap, tap, tap! Tom got a mop! 


\section{Story 10}

"Come and sit on the mat," says Miss Hill. "What did you bring to school, Flick?" says Miss Hill. Flick has a magnet. "It can pick up pins," she says. The pins stick to the magnet. The magnet picks up lots of clips too. The children clap. But Bill is not clapping. He is chatting to Fred. "Stop chatting to Fred," says Miss Hill. "Go and sit next to Jess." "What did you bring to school, Fred?" says Miss Hill. Fred has a box of shells. "I like this smooth pink shell best," he says. The children clap. But Bill is not clapping. He is chatting to Jess. "Stop chatting to Jess," says Miss Hill. "Go and sit next to the fish tank." "What did you bring in, Jess?" says Miss Hill. "This is my pet stick insect," says Jess. "It can lift its left leg." The stick insect lifts its leg. The children clap. But Bill is not clapping. He is chatting to the fish! "Stop chatting to the fish, Bill," says Miss Hill. "What did you bring in?" Bill stands up. He has a tooth in his hand. "Well?" says Miss Hill. But Bill just stands still. "Go on," says Miss Hill. "Tell us about the tooth." "But Miss," says Bill. "You said I had to stop chatting."

\section{Appendix 2: Reading Materails for Children From Education.com}

\section{Reading Material 1}

An Eagle swooped down upon a Serpent and seized it in his talons with the intention ${ }^{5}$ of carrying it o- and devouring $^{6}$ it. But the Serpent was too quick for him and had its coils round him in a moment; and then there ensued a life-and-death struggle between the two. A countryman, who was a witness of the encounter, came to the assistance of the eagle, and succeeded in freeing him from the Serpent and enabling him to escape. In revenge, the Serpent spat some of his poison into the man's drinking-horn. Heated with his exertions ${ }^{7}$, the man was about to slake his thirst with a draught ${ }^{8}$ from the horn, when the Eagle knocked it out of his hand, and spilled its contents upon the ground.

\section{Reading Material 2}

Once, a man and his son were going to the market with their donkey. As they walked a man passed them and said, "How silly. You are walking that donkey when you could be riding it instead. What is a donkey for but to ride on?" Hearing this, the man put his boy on the donkey's back and they went on their way. But soon they passed a group of women, one of whom said: "You should be ashamed of yourself young man. Your father who is older than you should be riding and you should be walking." Red-faced and embarrassed the boy jumped down to have his father get up on the donkey. They hadn't gone far when they passed a man and a woman, one of whom said to the other: "Doesn't he know they can both t on that donkey? His boy doesn't have to walk this dusty road." Well, the man didn't know what to do, but at last he took his son up and sat him down in front of him on the donkey. They reached the town and people began to jeer and point at them. "You're overloading that poor donkey -- you and your son both sitting there. You both look strong! You'd be better o- carrying the donkey yourselves." They got o- of the donkey and tried to think what to do. At last they cut down a pole and tied the donkey's feet to it. With it tied to the pole like this they raised the pole to their shoulders and carried the donkey towards the bridge that lead to the market. This was dicult to do. The townspeople laughed and heckled them so much that the donkey was frightened by everything going on. Its feet slipped loose from the ropes and it fell. Once it got to its feet again it ran away kicking and bucking. "That will teach you," said an old man who had followed them. "Try to please everyone and you will please no one."

\section{Reading Material 3}

My day started out great. I woke up to the sound of the birds chirping outside. I knew my grandma was making bacon for breakfast. The delicious smell drifted into my bedroom. Things looked good! We went to the beach near my grandma's house. The sun shone brightly. Grandma promised that I could get some ice cream from the Snack Bar. I really worked up an appetite for that ice cream after I swam in the water, built four sandcastles, and buried my friend's legs in the sand. Grandma gave me the money. I went to get my treat. As soon as I got back to the blanket where we sat, I ate my ice cream cone. Then it happened. The ice cream began to melt at a lightning speed and before I knew it, my ice cream was splattered in the sand.

\section{Reading Material 4}

You can make a tornado in the safety of your own home. Take two plastic bottles with screw-on caps. Glue the caps together so the tops are back-to-back. Ask a parent to help you make a hole through the glued bottle caps using a large nail. Fill one bottle about three-quarters full with water. Add food coloring and even some glitter so the tornado will be easy to see. Screw the double cap onto the bottle with water in it. Screw on the empty bottle at the top. Turn the two bottles upside down. Use both hands to hold the bottom bottle firmly. Use your wrists to 
turn the bottles as if you were drawing circles in the air. The water inside the bottles will start to swirl. You should see a tornado-like funnel form in the water.

\section{Reading Material 5}

Fireworks were invented in China in the 7th century. The story told is that a group of Chinese monks were trying to create a medicine that would give people immortality. Instead, they accidentally invented gunpowder, which is the explosive used in fireworks. Gunpowder was eventually used to for guns and bombs, but since its invention it has always been used for fireworks too. The Chinese would use the gunpowder as signal flares and for celebrations. Over time, people learned that if certain metals were mixed with the gunpowder brilliant colors could be made when it was ignited. Many more advancements have happened that let fireworks create all sorts of shapes and sounds, but they still work in the same way today. For a long time, fireworks have been a big part of Fourth of July celebrations in the United States. This is partly because they symbolize the rockets and explosions that Francis Scott Key wrote about in his song "The Star Spangled Banner."

\section{Reading Material 6}

The U.S. flag has undergone many changes since the first original flag in 1777. Before the official flag there had been many different flags that were popular in different colonies, but the Betsy Ross Flag was the first official national standard. In June 1776 George Washington asked Betsy Ross to sew a flag for the new country. He and a committee had come up with a design and requirements that it must have 13 stars and 13 stripes, each to stand for the colonies. The flag should be in red, blue and white. She designed the stars in a circle over a blue field. On June 14, 1777 the Continental Congress passed the Flag Act, which said that the flag would be made of white and red stripes and thirteen stars on blue. The number of stars were based on the 13 colonies and more stars were added as the US grew and got more states.

\section{Reading Material 7}

"There's a cyclone coming, Em," Uncle Henry called to his wife. "I'll go look after the stock." Then he ran toward the sheds where the cows and horses were kept. Aunt Em dropped her work and came to the door. One glance told her of the danger close at hand. "Quick, Dorothy!" she screamed. "Run for the cellar!" Toto jumped out of Dorothy's arms and hid under the bed, and the girl started to get him. Aunt Em, badly frightened, threw open the trap door in the fl oor and climbed down the ladder into the small, dark hole. Dorothy the floor and climbed down the ladder into the small, dark hole. Dorothy caught Toto at last and started to follow her aunt. When she was halfway caught Toto at last and started to follow her aunt. When she was halfway across the room there came a great shriek from the wind, and the house shook so hard that she lost her footing and sat down suddenly upon the fl oor. Then a strange thing happened. The house whirled around two or three times and rose slowly through the air. Dorothy felt as if she were going up in a balloon. In the middle of a cyclone the air is generally still, but the great pressure of the wind on every side of the house raised it up higher and higher, until it was at the very top of the cyclone; and there it remained and was carried miles and miles away as easily as you could carry a feather. It was very dark, and the wind howled horribly around her, but Dorothy found she was riding quite easily. She felt as if she were being rocked gently, like a baby in a cradle. Toto did not like it. He ran about the room, now here, now there, barking loudly; but Dorothy sat quite still on the floor and waited to see what would happen.

\section{Reading Material 8}

"Oh, how large he is!" "Isn't he? And such wonderfully strong legs!" "See his trunk, too! Isn't it cute! And he is well stued! -is is really one of the best toys that ever came into our shop, Geraldine; don't you think so?" "Yes, Angelina. I must call father to come and look at him. He will make a lovely present for some boy or girl--I mean this Stued Elephant will make a lovely present, not our father!" and Miss Angelina Mugg smiled at her sister across the big packing box of Christmas toys they were opening in their father's store. "Oh, no! Of course we wouldn't want father to be given away as a toy!" laughed Geraldine. "But this Stued Elephant--oh, I just love him!" Miss Geraldine Mugg caught up the rather large toy animal and hugged it tightly in her arms. "Be careful!" called her sister. "You may break him!" "Oh, he's just a Stued Elephant!" laughed Geraldine. "I mean he hasn't any works inside him to wind up. He's just full of cotton! But I am beginning to like him more than I care for some of the toys that do wind up. I almost wish I were small again, so I could have this Elephant for myself!" "He is nice," admitted Angelina. "Well, I'm glad they like me," thought the Stued Elephant to himself, for just now he was not allowed to speak out loud or move around, as the Make Believe toys could do at certain times. But these times were when no eyes of boys, girls, men or women were looking. 


\section{Reading Material 9}

Rosie wanted a kitten more than anything in the world. For months, she had dreamed of the day that she and her parents would go to the pound and adopt her brand new pet. But Rosie's mother insisted they wait until Rosie's birthday, which was still two months away. Rosie thought of kittens all day. She hoped hers would have blue eyes, fluffy fur, and a happy purr that Rosie would feel through her shirt when the kitten curled up on her chest. Walking home from school one day, she passed a neighbor's house and noticed a big cardboard box on the porch. Curious, she ventured closer and saw her neighbor, Mrs. Spencer, lifting a fluffy kitten from the box! The words "Free Kittens" were written across the side of the box in big, black letters. Mrs. Spencer saw Rosie eyeing the box and waved to her to come closer. "Your name is Rosie, isn't it? You live down the block." Rosie nodded and held her arms out for the kitten Mrs. Spencer was handing her to hold. It had blue eyes and its fur was as soft as Rosie had dreamed it would be. "Would you like to adopt that kitten?" asked Mrs. Spencer, smiling kindly. Before she knew what she was saying, Rosie blurted out, "Yes!" "Is it alright with your parents?" "It's fine. We've been planning to get a kitten for months." Though it wasn't the whole truth, Rosie couldn't help herself. She let Mrs. Spencer put the kitten into a little box, hand her a can of food, and send her on her way.

\section{Reading Material 10}

It was Saturday, the day of Rochelle's birthday party, and she was so excited she could hardly keep still. She had spent the whole morning decorating her house with streamers and balloons. She had set the table with matching plates, cups and napkins. Best of all, she had baked and iced cupcakes for each of her friends, without anyone else's help. Rochelle's little brother Remy was his usual bouncy self. "Happy birthday, Rochelle," he yelled, running around the kitchen and waving a balloon he'd torn down from the wall, where Rochelle had taped it up. "Calm down," she ordered. Remy's jumping was making the counters tremble and Rochelle feared her cupcakes would fall on the floor. "Get out of here, and quit tearing down my decorations or I won't give you the cupcake I made for you." Why did Rochelle ruin Remy's cupcake? "I get a cupcake? Yay!" Remy shouted, bouncing around as boisterously as ever. "Stop it, Remy, you'll ruin everything!” Rochelle wailed. Remy didn't stop. Finally, Rochelle picked up a cupcake. "This one was going to be yours," she told Remy, and threw it to the floor, where it landed upside down with a plop. Remy stopped bouncing, looked down at the cupcake, and began to cry.

\section{Copyrights}

Copyright for this article is retained by the author(s), with first publication rights granted to the journal.

This is an open-access article distributed under the terms and conditions of the Creative Commons Attribution license (http://creativecommons.org/licenses/by/4.0/). 